\title{
ANALISIS PENERAPAN ZAKAT SEBAGAI ALAT PERENCANAAN PAJAK (TAX PLANNING) PPh BADAN PADA PT TELKOM INDONESIA
}

\author{
Asyraf Mustamin ${ }^{1}$, Amrah Kasim ${ }^{2}$, Ismawati ${ }^{3}$, Murliani $^{4}$ \\ ${ }^{1}$ UIN Alauddin Makassar, asyraf_citizen@windowslive.com \\ ${ }^{2}$ UIN Alauddin Makassar, Amrah_kasim@yahoo.com \\ ${ }^{3}$ UIN Alauddin Makassar, Ismawatiabbas77@yahoo.com \\ ${ }^{4}$ STAI YPIQ Baubau, murliani51@gmail.com
}

\begin{abstract}
ABSTRAK
Penelitian ini bertujuan untuk mengetahui pengaruh penerapan zakat sebagai alat perencanaan pajak dan menguji bukti empiris efisiensi PPh badan pada PT Telkom Indonesia Tbk Makassar untuk laporan keuangan dan laporan perpajakan mulai tahun 2011-2013. Teknik pengumpulan data yaitu penelitian lapangan studi kasus dengan menganalisis data kuantitaif dan menghasilkan data kualitatif. Objek yang diteliti ialah dokumentasi data-data pada PT Telkom Indonesia Tbk. Berdasarkan hasil penelitian menunjukkan bahwa PT Telkom Indonesia Tbk Makassar telah melakukan pelaporan perpajakan sesuai dengan peraturan perpajakan yaitu Undang-undang No.36 tahun 2008, setelah melakukan perhitungan Pajak Penghasilan (PPh) badan setelah diterapkan zakat sebagai alat perencanaan pajak serta perusahaan wajib mengeluarkan zakat karena keberadaan perusahaan adalah sebagai badan hukum (recht person) atau yang dianggap sebagai orang. Hasil perhitungan perencanaan pajak setelah dilakukan penerapan zakat terdapat potensi efisiensi sebesar 6,3\% sehingga hasil perhitungan $\mathrm{PPh}$ Badan dengan melakukan penerapan zakat lebih efisien dibandingkan tanpa melakukan penerapan zakat sebagai alat perencanaan pajak.
\end{abstract}

Kata Kunci: Zakat, Perencanaan Pajak, dan Efisiensi

\section{ABSTRACT}

This study aims to determine the effect of the application of zakat as a tax planning tool and test the empirical evidence of the efficiency of corporate income tax at PT Telkom Indonesia Tbk Makassar for financial reports and tax reports starting in 2011-2013. Data collection techniques are case study field research by analyzing quantitative data and producing qualitative data. The object under study is the documentation of data on PT Telkom Indonesia Tbk. Based on research results show that PT Telkom Indonesia Tbk Makassar has done tax reporting in accordance with tax regulations namely Law No.36 of 2008, after calculating the corporate income tax (PPh) after applying zakat as a tax planning tool and the company is obliged to issue zakat because the existence of a company is a legal entity (recht person) or is considered a person. The results of the calculation of tax planning after the application of zakat there is a potential efficiency of $6.3 \%$ so that the results of the calculation of Corporate Income Tax by implementing zakat are more efficient than without implementing zakat as a tax planning tool.

Keywords: Zakat, Tax Planning, and Efficiency

Naskah diterima: 06-03-2020, Naskah dipublikasikan: 30-04-2020

\section{PENDAHULUAN}

Sistem keuangan syariah menjadi salah satu altertanif perekonomian yang sangat potensial karena dianggap lebih aman, tidak spekulatif, mudah, dan cenderung menguntungkan kepada semua pihak. Saat ini pun bank-bank sentral Eropa, Asia, Afrika, bahkan Amerika mulai memperkenalkan sistem keuangan syariah dengan tujuan yaitu sebagai penggerak baru ekonomi dunia ekonomi syariah dianggap mampu bersaing secara global, salah satu contohnya ialah 
lebih dari 1.300 pemimpin industri dari lebih 50 negara dunia baru-baru ini berkumpul pada satu pertemuan World Islamic Banking Confrence (WIBC) di Bahrain untuk membahas mengenai transformasi industri menuju sistem syariah (Erik dalam Republika, 2013).

Di Indonesia sendiri dalam pengembangan ekonomi syariah menurut beberapa sumber masih rendah karena masih banyak masyarakat yang belum menyadari betapa pentingnya penerapan ekonomi syariah di Indonesia padahal Gubernur Bank Indonesia sendiri mengakui bahwa perekonomian syariah telah menunjukkan kapabilitasnya bertahan dari krisis. Hal ini dikarenakan sistem ini sejak semula telah menghindarkan diri dari bahaya spekulasi, padahal dari segi potensi menurut hasil penelitian Thomson Reuters bertema State of the Global Islamic Economy: 2013 Report, Indonesia masuk sebagai salah satu pasar perekonomian Islam yang potensial. Indonesia menduduki peringkat ke-5 dengan ukuran potensi sebesar \$ 375 miliar pada 2012, berada di bawah Turki (\$ 775 miliar), Iran (\$ 512 miliar), Arab Saudi (\$ 461 miliar), dan Uni Emirat Arab (\$381 miliar) namun Indonesia hanya mengandalkan sebagaian besar penerimaan negaranya dari sektor pajak (Didik dalam Tribun Timur, 2013).

Dalam perpajakan perbedaan yang mendasar dalam hal kepentingan antara Wajib Pajak dengan pemerintah adalah: Wajib Pajak cenderung untuk meminimalkan jumlah pembayaran pajak, sebaliknya pemerintah mengharapkan penerimaan pajak yang maksimal. Berdasarkan hal tersebut jika tidak dijembatani dengan baik maka akan merugikan negara ini. Bagi Wajib Pajak yang ingin meminimalkan pembayaran pajak guna mengoptimalkan laba dengan cara yang legal maka dapat dengan melakukan perencanaan pajak. Perencanaan pajak merupakan satu-satunya cara yang legal untuk meminimalkan pembayaran pajak oleh Wajib Pajak dengan tidak melanggar undang-undang. Salah satu hal yang dapat menjadi komponen perencanaan pajak yaitu dengan memasukan zakat sebagai pengurang penghasilan kena pajak.

Masyarakat Indonesia yang merupakan wajib pajak dalam negeri mayoritas beragama Islam, menurut data di Wikipedia tahun 2010 kira-kira 85,1\% dari 240.271 .522 penduduk Indonesia adalah pemeluk agama Islam dan merupakan jumlah muslim terbesar di dunia. Berkaitan dengan harta dan penghasilan umat Islam, terdapat kewajiban berupa zakat bagi yang telah memenuhi syarat. Di sisi lain, sebagai warga negara Indonesia, umat Islam juga memiliki kewajiban pajak bagi yang telah memenuhi syarat, karena telah dibuat undangundang yang mewajibkan itu. Hal ini terlihat jelas dengan adanya dua kewajiban dalam dua undang-undang yang berbeda, yaitu kewajiban zakat dalam UU No. 38 Tahun 1999 tentang pengelolaan zakat yang isinya antara lain mengenai tujuan pengelolaan zakat yaitu:

1. Meningkatnya pelayanan bagi masyarakat dalam menunaikan zakat sesuai dengan tuntunan agama

2. Meningkatnya fungsi dan peranan pranata keagamaan dalam upaya mewujudkan kesejahteraan masyarakat dan keadilan sosial

3. Meningkatnya hasil guna dan daya guna zakat.

Adapun UU No 36 Tahun 2008 tentang Pajak Penghasilan yaitu mengenai tujuan Pajak ialah dalam rangka meningkatkan daya saing dengan negera-negara lain, mengedepankan prinsip keadilan dan netralitas dalam penetapan tarif, dan memberikan dorongan bagi berkembangnya usaha-usaha kecil, struktur tarif pajak yang berlaku juga perlu diubah dan disederhanakan yang meliputi penurunan tarif secara bertahap, terencana, pembedaan tarif, serta penyederhanaan lapisan yang dimaksudkan untuk memberikan beban pajak yang lebih proporsional bagi tiap-tiap golongan Wajib Pajak tersebut.

Kedua undang-undang tersebut menyatakan bahwa zakat dan pajak adalah kewajiban. Menyikapi kewajiban pajak berdasarkan undang-undang, terdapat beberapa pendapat di kalangan umat Islam dari yang pro maupun yang kontra karena telah ada kewajiban zakat terhadap harta dan peng- hasilannya yang telah memenuhi syarat. Pajak dan zakat memang memiliki kesamaan namun dengan adanya kesamaan, bukan berarti pajak bisa begitu saja disamakan dengan zakat. Sebab keduanya ada perbedaan-perbedan yang sangat mendasar. Pajak bisa digunakan untuk membangun jalan raya, dan dalam banyak hal bisa lebih leluasa dalam penggunaannya. Sedangkan, zakat dalam penggunaannya akan terikat aturan yang tercantum 
dalam Al Quran. Zakat dengan dalih apapun tidak dapat disamakan dengan pajak.

Namun bukan berarti zakat dan pajak tidak dapat saling mempengaruhi sama sekali, dalam kajian keuangan negara dan ekonomi pembangunan, sistem zakat disebut-sebut sebagai sebuah sistem yang mirip dengan sistem perpajakan. Fatwa ulama mengenai hal ini pun cukup beragam dan pada dasarnya memiliki persamaan dari segi kewajiban yang cukup mengakar dan membudaya. Salah satu penelitian yang pernah dilakukan oleh Haekal Reza berjudul Mengangkat nilai "Zakat dengan hati" refleksi fenomenologis zakat perusahaan pengusaha Arab membahas mengenai refleksi zakat bagi perusahaan secara filosofis menyimpan potensi besar yang belum maksimal dijalankan sehingga menjadi inspirasi bagi kami untuk mengangkat penelitian dengan berlandaskan filosofi penelitian tersebut ke penelitian yang lebih teknis mengenai potensi zakat perusahaan yang dapat dijadikan sebagai instrument dalam menyusun perencanaan pajak sehingga pada akhirnya dapat menjadi model yang dapat dikembangkan bagi perusahaan serta pengusaha muslim pada umumnya.

\section{KAJIAN LITERATUR \\ Zakat}

Syekh Muhamad bin Soleh al-Utsaimin menyampaikan Zakat adalah satu kewajiban dari kewajiban-kewajiban islam, ia adalah salah satu dari rukun-rukunnya, dan termasuk rukun yang terpenting setelah syahadat dan solat, Kitab dan sunnah serta ijma' telah menunjukan kewajibanya, barang siapa mengingkari kewajibanya maka ia adalah kafir dan murtad dari islam harus diminta agar bertaubat, jika tidak bertaubat dibunuh, dan barang siapa kikir dengan enggan mengeluarkan zakat atau mengurangi sesuatu derinya maka ia termasuk orang-orang dzolim yang berhak atas sangsi dari Allah SWT.

Zakat merupakan salah satu rukun Islam, dan menjadi salah satu unsur pokok bagi tegaknya syariat Islam. Oleh sebab itu hukum zakat adalah wajib (fardhu) atas setiap muslim yang telah memenuhi syarat-syarat tertentu. Zakat termasuk dalam kategori ibadah, seperti salat, haji, dan puasa yang telah diatur secara rinci dan paten berdasarkan Al-Qur'an dan As Sunnah, sekaligus merupakan amal sosial kemasyarakatan dan kemanusiaan yang dapat berkembang sesuai dengan perkembangan ummat manusia. (Al Habib: 2007)

Zakat adalah merupakan pembersihan dan pensucian terhadap jiwa seorang hamba Allah. Firman Allah Ta'ala:

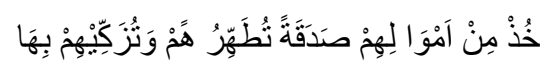

Artinya: Ambillah Zakat dari sebagian harta mereka dengan zakat itu kamu memberikan dan mensucikan mereka. (QS.9:103).

\section{Perencanaan Pajak Penghasilan (PPh) Badan}

Untuk memahami arti daripada pajak, terdapat beberapa Definisi yang dipaparkan oleh para ahli yang dikutip dari karangan purwono (2010:6) antara lain sebagai berikut: Menurut Leroy Beaulieu: "Pajak adalah bantuan secara langsung maupun yang tidak dipaksakan oleh kekuasaan politik dari penduduk atau dari barang, untuk menutup belanja pemerintah". Sedangkan menurut Deutche Reich Abgaden ordnung dalam Pohan (2013): Pajak sebagai bantuan uang insidental atau secara periodik yang dipungut oleh badan yang bersifat umum untukmemperoleh pendapatan ketika terjadi suatu tatbestand karena undang-undang telah menimbulkan utang pajak.

Tujuan utama perencanaan pajak adalah mencari berbagai celah yang dapat ditempuh dalam koridor peraturan perpajakan (loopholes), agar perusahaan dapat membayar pajak dalam jumlah minimal. Dalam perencanaan pajak ada 3 macam yang dapat dilakukan wajib pajak untuk menekan jumlah beban pajaknya, yakni penghindaran pajak (Tax Avoidance), penyelundupan pajak (Tax evasion), penghematan pajak (Tax Saving). Penghidaran pajak adalah strategi dan teknik penghindaran pajak dilakukan secara legal dan aman bagi wajib pajak karena tidak bertentangan dengan ketentuan pajak. Metode dan teknik yang digunakan adalah 
memanfaatkan kelemahan (grey area) yang terdapat dalam undang-undang dan peraturan perpajakan itu sendiri (Pohan, 2013).

Penyelundupan pajak (Tax Evasion) adalah kebalikan dari penghindaran pajak (Tax Avoidance), strategi dan tekni penghindaran pajak dilakukan secara legal dan tidak aman bagi wajib pajak, cara penyelundupan ini bertentangan dengan ketentuan perpajakan karena metode dan teknik yang digunakan tidak berada dalam koridor undang-undang dan peraturan perpajakan. Cara yang ditempuh beresiko tinggi dan berpotensi dikenakannya sanksi pelanggaran hukum atau tidak pidana fiskal atau kriminil. Oleh sebab itu seorang tax planner yang baik tidak direkomendasikan tax evasion, sedangkan penghematan pajak (Tax Saving) adalah merupakan suatu tindakan penghematan pajak yang dilakukan oleh wajib pajak yang aman dan tidak bertentangan dengan ketentuan perpajakan (Pohan, 2013).

\section{Persamaan dan Perbedaan zakat dan Pajak.}

Zakat adalah rukun Islam yang langsung bersentuhan dengan aspek-aspek sosial kemasyarakatan, itu terlihat pada Rukun Islam yang ketiga, yaitu menunaikan zakat. Orang yang berzakat dengan baik, dengan ikhlas, insya Allah dia akan menjadi orang yang sholeh. Kita seringkali beranggapan bahwa setelah membayar Pajak, tidak perlu lagi membayar Zakat. Atau sebaliknya sudah membayar Zakat, untuk apa lagi kita harus membayar Pajak. (Nurcholis, 2010).

Memang ada banyak kesamaan antara pajak dengan zakat, tetapi tidak bisa dipungkiri bahwa antara kedua tetap ada perbedaan yang hakiki. Sehingga keduanya tidak bisa disamakan begitu saja. Persamaan zakat dengan pajak adalah sebagai berikut:

1. Bersifat wajib dan mengikat atas harta penduduk suatu negeri, apabila melalaikannya terkena sanksi.

2. Zakat dan pajak harus disetorkan pada lembaga resmi agar tercapai efisiensi penarikan keduanya dan alokasi penyalurannya.

3. Dalam pemerintahan Islam, zakat dan pajak dikelola oleh negara.

4. Tidak ada ketentuan memperoleh imbalan materi tertentu didunia.

5. Dari sisi tujuan ada kesamaan antara keduanya yaitu untuk menyelesaikan problem ekonomi dan mengentaskan kemiskinan yang terdapat di masyarakat.

Pemerintah sudah seharusnya mengatur dan menyandingkan manajemen zakat dan pajak pada kedudukan yang sama, karena bila masyarakat sudah taat membayar zakat, maka Pemerintah pun memperoleh kemudahan dengan dapat membantu Fakir dan Miskin yang seharusnya dibantu oleh Negara, sehingga orang yang sudah memiliki Nomor Pokok Wajib Zakat (NPWZ) dan membayar zakat, kewajiban membayar pajaknya dikurangi zakat yang telah dikeluarkan. Misalnya PPh terhadap penghasilan (profesi) di atas Rp. 50.000.000,00 s.d Rp. 250.000.000,00 adalah 15\% (Tarif PPh Pasal 17 UU PPh No 36 tahun 2008). Subyek pajaknya sudah membayar zakat sebesar 2,5\%, maka tinggal membayar Pajak kekuarangannya, yaitu $15 \%-2,5 \%=12,5 \%$. Untuk lebih memikat muzakki, memang mestinya zakat yang semula hanya sebagai pengurang penghasilan kena pajak (PPKP) ditingkatkan menjadi pengurang pajak (tax deductible). Dengan demikian, fungsi zakat sebagai penghargaan (reward) terhadap pembayar pajak, menjadi lebih signifikan. Dengan kebijakan itu, meski pajak secara presentase menjadi lebih kecil namun proyeksi total amount-nya akan lebih besar seiring besarnya semangat rakyat membayar pajak. (Nurcholis, 2010).

Banyak penelitian yang dipublikasikan memuat bagaimana besarnya potensi zakat terhadap penerimaan negara yang amat besar seperti penelitian yang dilakukan oleh thamrin dkk mengenai peranan zakat sebagai pengurang penghasilan kena pajak di kantor kementerian agama kabupaten gowa dan juga penelitian yang dilakukan oleh khairrizal tentang zakat sebagai pengurangan penghasilan kena pajak menunjukkan begitu potensialnya zakat sebagai pendukung pemasukan negara selain pajak. 


\section{METODE PENELITIAN}

Menurut Sugiyono (2011:31) bahwa variabel adalah salah satu atribut sifat dan nilai dari individu, objek atau kegiatan yang mempunyai variasi tertentu yang diharapkan untuk dipelajari dan ditarik kesimpulannya. Berdasarkan topik penelitian yang akan dibahas maka variabel yang digunakan dalam penelitian ini adalah Penerapan zakat dan perencanaan pajak Penghasilan (PPh) Badan. Penelitian ini merupakan penelitian deskriptif. Penelitian ini menggambarkan data yang diperoleh dan menganalisis data yang ada.

Penelitian deskriptif bertujuan untuk mendeskripsikan fakta yang saat ini berlaku. Di dalamnya terdapat upaya-upaya mendeskripsikan, mencatat, analisis, dan menginterpretasikan kondisi-kondisi yang sekarang ini terjadi (Moh. Pabundu Tika, 2006: 10). Desain penelitian ini adalah studi kasus dengan menggunakan data periode lalu. Studi kasus merupakan penelitian dengan karakteristik masalah yang berkaitan dengan latar belakang dan kondisi saat ini dari subjek yang diteliti serta interaksinya dengan lingkungan. Subjek yang diteliti dapat berupa individu, kelompok, lembaga atau komunitas tertentu. Tujuan studi kasus adalah melakukan penyelidikan secara mendalam mengenai subjek tertentu untuk memberikan gambaran yang lengkap mengenai subjek tertentu (Nur Indriantoro dan Bambang Supomo, 2002: 26).

Dalam penelitian ini, penelitian ini adalah Analisis penerapan zakat sebagai alat perencanaan pajak (Tax Planning) PPh Badan pada PT Telkom Makassar. Adapun alat ukur yang digunakan yaitu: Zakat yaitu diukur dengan angka 2,5 dan mengalikan seratus dengan satuan ukur persen (\%), Perencanaan pajak diukur dari besarnya perencanaan pajak yang akan dibayarkan oleh perusahaan dan dinyatakan dalam satuan ukur rupiah $(\mathrm{Rp})$.

Untuk pengujian dalam penelitian ini, digunakan metode deskriptif komparatif yaitu memberikan gambaran dan uraian mengenai penentuan Perencanaan pajak PPh Badan dengan menggunakan penghitungan zakat dan membandingkannya dengan perencanaan pajak sebelumnya. Analisis data yang digunakan untuk penentuan Perencanaan pajak PPh Badan dengan menggunakan penghitungan zakat adalah sebagai berikut:

1) Mendokumentasikan laporan keuangan yang terjadi pada tahun 2011-2013.

2) Menghitung pajak setelah diterapkan penghitungan zakat dalam periode berjalan berdasarkan laporan keuangan periode sebelumnya dengan rumus penghitungan pajak seperti berikut ini:

Rumus perhitungan Pajak penghasilan (PPh) Badan menurut Mufraini Arief (2008:52) adalah sebagai berikut:

Pendapatan usaha

$\operatorname{Rp} x x x$

Dikurangi:

Harga pokok penjualan $\mathrm{Rp} x \mathrm{xx}$

Biaya Usaha Lainnya $\quad \operatorname{Rp} x x x$

Gaji Rp xxx

Bunga Rp xxx

Royalti Rpxxx

Sewa $\quad \operatorname{Rp} x x x$

Jasa $\quad \underline{\operatorname{Rpxxx}+}$

Laba sebelum pajak

Zakat $(2,5 \%$ x xxx)

Dasar pengenaan pajak

Pajak Penghasilan (Tarif x xxx)

3) Menyusun perhitungan perencanaan setelah pengaplikasian zakat.

4) Membandingkan hasil perhitungan perencanaan pajak yang dihitung berdasarkan setelah pengaplikasian zakat dan sebelum pengaplikasiannhya kemudian menghitung selisihnya.

5) Menganalisis tingkat efisiensi pajak yang dibayarkan di PT Telkom Indonesia di kota Makassar. 


\section{HASIL DAN PEMBAHASAN}

Dasar Hukum Penerapan Zakat sebagai alat perencanaan Pajak penghasilan (PPh) Badan

Pada saat ini hampir sebagian besar perusahaan tidak dikelola secara individual, melainkan secara bersama-sama dalam sebuah kelembagaan dan organisasi dengan manajemen yang modern termasuk PT Telkom Indonesia Tbk itu sendiri. Menurut para ahli ekonomi sekarang paling tidak ada tiga kelompok jenis perusahaan, pertama perusahaan yang menghasilkan produk-produk tertentu, kedua perusahaan yang bergerak dibidang jasa dan ketga perusahaan yang bergerak dibidang keuangan (Hafidhudin, 2008). Qardhrawi dalam Farkhruddin menyebutnya dengan istilah al-mustaghallat, yaitu harta benda yang tidak diperdagangkan akan tetapi disewakan atau dijual hasil produksinya, benda hartanya tetap, akan tetapi manfaatnya berkembang. Yang dimaksud dengan perusahaan dalam konteks perhitungan zakat adalah sebuah usaha yang di organisir sebagai sebuah kesatuan resmi yang terpisah dengan kepemilikan dibuktikan dengan kepemilikan saham (Mufraini, 2008).

Perusahaan wajib mengeluarkan zakat karena keberadaan perusahaan adalah sebagai badan hukum (recht person) atau yang dianggap sebagai orang. oleh karena itu diantara individu itu kemudian timbul transaksi meminjam, menjual, berhubungan dengan pihak luar, dan juga menjalin kerja sama. Segala kewajiban dan hasil akhirnyapun dinikmati secara bersama-sama, termasuk di dalamannya kewajiban kepada Allah Swt dalam bentuk zakat. Kewajiban zakat perusahaan juga didukung oleh hadist riwayat Bukhari dari Anas bin Malik, bahwasanya Abu Bakar menulis surat kepadanya yang berisikan pesan singkat kepadanya yang berisikan pesan tentang zakat binatang ternak yang didalamnya ada unsur syirkah. Sebagian isi surat itu antara lain "jangan dipisahkan sesuatu yang telah tergabung (berserikat) karena takut mengeluarkan zakat. Dan apa-apa yang telah digabungkan dari dua orang yang telah berserikat (berkongsi), maka keduanya harus dikembalikan (diperjuangkan) secara sama". Teks hadis tersebut sebenarnya berkaitan dengan dengan pengkongsian binatang ternak, akan tetapi ulama menerapkannya sebagai dasar qiyas untuk pengkongsian yang lain seperti pengkongsian dalam perusahaan. Dengan dasar ini maka keberadaan perusahaan sebagai wadah usaha dipandang sebagai syakhsiyah hukmiyah. Para individu diperusahaannya. Segala kewajiban ditanggung bersama dan hasil akhirpun dinikmati bersama, termasuk di dalamnya kewajiban kepada Allah yakni zakat harta. Tentang bagaimana dan kapan zakat perusahaan itu dikeluarkan Al-Hambali dan madzhab Hadawiyah menyatakan pendapatnya bahwa perusahaan disamakan dengan harta perdagangan.karena itu tiap-tiap akhir tahun semua modal diperhitungkan termasuk masukan yang ada dan apabila jumlah keseluruhannya mencapai satu nishab yaitu seharga 85 gram ataau 94 gram emas murni kemudian dipungut $2,5 \%$ untuk zakat.

Zakat dalam informasi akuntansi juga dapat digunakan sebagai alat untuk mengukur kinerja perusahaan, jika perusahaan tersebut telah menggunakan metafora amanah sebagai ukuran kinerjanya. Pada tahap akhir dari proses pengendalian manajemen, akuntansi zakat dibutuhkan untuk pembuatan laporan keuangan yang merupakan bagian penting dari proses akuntabilitas publik (konsep amanah). Salah satu hal yang penting dalam akuntansi untuk setiap kejadian transaksi adalah bagaimana perlakuan akuntansi terhadap akun-akun yang bersangkutan. Perlakuan akuntansi untuk zakat perusahaan harus tetap mengacu pada prinsip dan ketentuan untuk zakat perusahaan secara umum yakni adanya harta ketetapan akan haul yakni kepemilikan harta selama tahun hijriah. Prinsip tahunan dalam akuntansi berkaitan dengan periodesasi pembuatan dan pelaporan keuangan.

Inilah yang menjadi garis merah keterkaitan antara dua hal tersebut hal ini ditekankan dalam prinsip ini ialah naik turunnya nilai asset yang dimiliki selama satu haul berjalan tidak menjadi pertimbangan dalam kewajiban zakat, yang terpenting adalah nilai asset pada akhir masa haul. Pencatatan dan pelaporan akuntansi untuk dana zakat ini dilakukan setelah zakat itu mencapai haul. (Mufraini, 2008). 


\section{Analisis Besarnya PPh terutang sebelum penerapan zakat pada PT Telkom Indonesia Tbk} Makassar

Analisis besarnya pajak penghasilan terutang sebelum penerapan zakat yaitu berdasarnyan perhitungan pajak penghasilan badan menurut undang-undang perpajak No. 17 tahun 200, yaitu tarif $\mathrm{PPh}$ yang terdiri yakni terdiri dari pajak kini dan pajak tangguhan berdasarkan data laporan keuangan pada PT Telkom Indonesia Tbk.

Untuk lebih jelasnya dapat dilihat data perhitungan pajak penghasilan pada PT Tellkom Indonesia Tbk selama tiga tahun yakni tahun 2011 sampai dengan tahun 2013 berikut ini:

Tabel 1. Pajak penghasilan PT Telkom Indonesia Tbk Tahun 2011

\begin{tabular}{|c|c|}
\hline $\begin{array}{r}\text { PT TELKOM INDON } \\
\text { PERHITUNGAN PAJAK PENGH } \\
\text { (Milyar Rupi }\end{array}$ & \\
\hline Laba Sebelum Pajak Penghasilan & $\operatorname{Rp} 20.857$ \\
\hline \multicolumn{2}{|l|}{ Pajak Penghasilan Terutang: } \\
\hline Pajak Kini (laba x 25\%) & ( Rp 5.673) \\
\hline Pajak Tangguhan & $\begin{array}{r}\operatorname{Rp} 286 \\
(\operatorname{Rp} 5.387)\end{array}$ \\
\hline Laba Tahun Berjalan & Rp 15.470 \\
\hline
\end{tabular}

Sumber: Hasil pengolahan data

Berdasarkan tabel 1 di atas, perhitungan pajak penghasilan pada tahun 2011 menggambarkan bahwa laba sebelum pajak yang diperoleh oleh perusahaan adalah sebesar Rp 20.857 Milyar. Dari laba tersebut, pajak yang harus dibayarkan menurut undang-undang perpajakan no 36 Tahun 2008 adalah sebesar 25\% disesuaikan dengan kondisi perusahaan yakni ditambah dengan pajak tangguhan (Deferred Tax Liabiliies) pada tahun pajak periode sebelumnya dan dikurangi dengan pajak tangguhan tahun berjalan seperti yang diketahui bahwa pajak tangguhan adalah Jumlah pajak penghasilan yang terutang untuk periode mendatang sebagai akibat perbedaan temporer kena pajak (taxable temporary differences).

Perbedaan temporer timbul sebagai konsekuensi logis dari adanya perbedaan standar atau ketentuan yang berkaitan dengan pengakuan (kriteria dan periode), dan pengukuran atau penilaian elemen-elemen laporan keuangan yang berlaku dalam disiplin akuntansi perpajakan (ketentuan perpajakan) disatu pihak dengan standar atau ketentuan yang berlaku dalam disiplin akuntansi keuangan dipihak yang lain. Sehingga pajak yang harus dibayar oleh perusahaan pada tahun 2011 adalah sebesar Rp 5.387 Milyar.

Tabel 2. Pajak penghasilan PT Telkom Indonesia Tbk Tahun 2012

\begin{tabular}{|cr|}
\hline \multicolumn{2}{|c|}{ PT TELKOM INDONESIA TBK } \\
PERHITUNGAN PAJAK PENGHASILAN TAHUN 2012 \\
(Milyar Rupiah)
\end{tabular}

Sumber: Hasil pengolahan data 
Berdasarkan tabel 2 di atas, perhitungan pajak penghasilan pada tahun 2012 menggambarkan bahwa laba sebelum pajak yang diperoleh oleh perusahaan adalah sebesar Rp 24.228 Milyar. Dari laba tersebut, pajak yang harus dibayarkan menurut undang-undang perpajakan no 36 Tahun 2008 adalah sebesar 25\% disesuaikan dengan kondisi perusahaan yakni ditambah dengan pajak tangguhan (Deferred Tax Liabiliies) pada tahun pajak periode sebelumnya dan dikurangi dengan pajak tangguhan tahun berjalan seperti yang diketahui bahwa pajak tangguhan adalah Jumlah pajak penghasilan yang terutang untuk periode mendatang sebagai akibat perbedaan temporer kena pajak (taxable temporary differences).

Perbedaan temporer timbul sebagai konsekuensi logis dari adanya perbedaan standar atau ketentuan yang berkaitan dengan pengakuan (kriteria dan periode), dan pengukuran atau penilaian elemen-elemen laporan keuangan yang berlaku dalam disiplin akuntansi perpajakan (ketentuan perpajakan).sehingga pajak yang harus dibayar oleh perusahaan pada tahun 2011 adalah sebesar Rp 5.866 Milyar.

Tabel 3. Pajak penghasilan PT Telkom Indonesia Tbk Tahun 2013

\begin{tabular}{|cr|}
\hline $\begin{array}{c}\text { PT TELKOM INDONESIA TBK } \\
\text { (Milyar Rupiah) }\end{array}$ & \\
PERHITUNGAN PAJAK PENGHASILAN TAHUN 2013 & \\
\hline Laba Sebelum Pajak Penghasilan & $\mathrm{Rp} .149$ \\
Pajak Penghasilan Terutang: & $(\mathrm{Rp} \mathrm{6.995)}$ \\
Pajak Kini (laba x 25\%) & $\underline{\mathrm{Rp} \mathrm{136}}$ \\
Pajak Tangguhan & $(\mathrm{Rp} \mathrm{6.859)}$ \\
& $\mathrm{Rp} \mathrm{20.402}$ \\
\hline
\end{tabular}

Sumber: Hasil data diolah

Berdasarkan tabel 3 di atas, perhitungan pajak penghasilan pada tahun 2013 menggambarkan bahwa laba sebelum pajak yang diperoleh oleh perusahaan adalah sebesar Rp 27.149 Milyar. Dari laba tersebut, pajak yang harus dibayarkan menurut undang-undang perpajakan no 36 Tahun 2008 adalah sebesar 25\% disesuaikan dengan kondisi perusahaan yakni ditambah dengan pajak tangguhan (Deferred Tax Liabiliies) pada tahun pajak periode sebelumnya dan dikurangi dengan pajak tangguhan tahun berjalan seperti yang diketahui bahwa pajak tangguhan adalah Jumlah pajak penghasilan yang terutang untuk periode mendatang sebagai akibat perbedaan temporer kena pajak (taxable temporary differences). Sehingga pajak yang harus dibayar oleh perusahaan pada tahun 2011 adalah sebesar Rp 6.859 Milyar.

Berikut gambaran data besarnya pajak yang disajikan oleh PT Telkom Indonesia Tbk pada tahun 2011-2013 setelah data diolah oleh peneliti.

Tabel. 4 Pajak penghasilan PT Telkom Indonesia Tbk mulai tahun 2011-2013 (Milyar Rupiah)

\begin{tabular}{ccc}
\hline Tahun & Besarnya Pajak & Selisih \\
\hline $\mathbf{2 0 1 1}$ & Rp 5.387 & - \\
$\mathbf{2 0 1 2}$ & Rp 5.866 & Rp 193 \\
$\mathbf{2 0 1 3}$ & Rp 6.859 & Rp 1.029 \\
\hline Jumlah & Rp 18.434 & Rp1.222 \\
\hline
\end{tabular}

Sumber: Hasil data diolah 
Pada tabel 4 dapat dilihat besarnya pajak penghasilan yang dibayarkan oleh PT Telkom Indonesia Tbk dalam kurun waktu 3 tahun yaitu tahun 2011-2013. Berdasarkan Undang-undang Nomor 36 Tahun 2008, dimana tarif pajak untuk Wajib Pajak badan adalah tarif yang dibayarkan sebesar 25\%, sehingga tahun 2011 pajak terutangnya adalah Rp 5.673 Milyar, tahun 2012 pajak terutangnya Rp 5.866 Milyar, dan 2013 pajak terutangnya adalah Rp 6.859 Milyar.

Secara umum pajak penghasilan pada tahun 2011-2013 meningkat. Dari tahun 2011 ke tahun 2012 pajak penghasilan meningkat dipengaruhi oleh kenaikan penghasilan yakni sebesar Rp 193 Milyar atau dengan presentase sebesar 3,4\%, begitupun dari tahun 2012 ke tahun 2013 meningkat sebesar Rp 1.029 atau dengan presentase kenaikan sebesar 17,5\%. Secara visual besarnya peningkatan pajak pada PT Telkom Indonesia dari tahun 2011-2013 dapat dilihat pada grafik berikut:

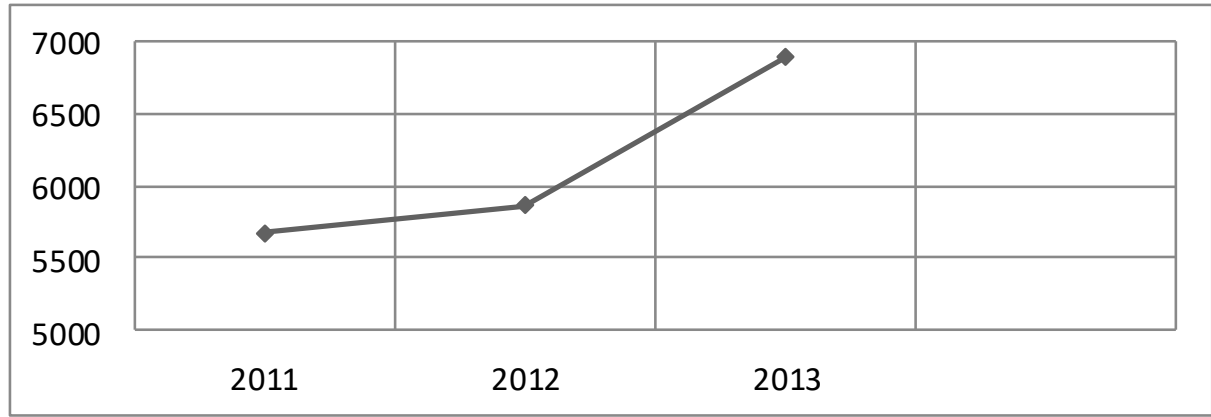

Gambar 1. Grafik Besaran Pajak penghasilan PT Telkom Indonesia tahun 2011-2013.

Pada grafik 1 terlihat dengan jelas besaran pajak penghasilan terutang PT Telkom Indonesia Tbk mengalami peningkatan dari tahun 2011-2013 dipengaruhi oleh penghasilan perusahaan tersebut.

\section{Analisis Besarnya PPh terutang setelah penerapan zakat pada PT Telkom Indonesia Tbk Makassar}

Analisis besarnya pajak penghasilan terutang setelah penerapan zakat pada PT Telkom Indonesia Tbk Makassar yaitu berdasarkan hadis Rasulullah Saw yaitu sebesar 2,5\% dari hasil pendapatan.

Untuk lebih jelasnya dapat dilihat data perhitungan pajak penghasilan setelah penerapan zakat untuk tahun 2011-2013 berikut ini:

Tabel 5. Pajak penghasilan setelah penerapan zakat pada PT Telkom Indonesia Tbk

Tahun 2011

\begin{tabular}{|cr|}
\hline $\begin{array}{c}\text { PT TELKOM INDONESIA TBK } \\
\text { PERHITUNGAN PAJAK PENGHASILAN TAHUN 2011 } \\
\text { (Milyar Rupiah) }\end{array}$ \\
\hline Laba & $\operatorname{Rp~20.875}$ \\
Zakat & $(\mathrm{Rp} \mathrm{521)}$ \\
Laba sebelum Pajak & $\mathrm{Rp} \mathrm{20.336}$ \\
Pajak Penghasilan Terutang: & $(\operatorname{Rp~5.048)}$ \\
Pajak Kini & $\underline{\operatorname{Rp} 286}$ \\
Pajak Tangguhan & $(\operatorname{Rp~4.798)}$ \\
Laba Tahun Berjalan & $\operatorname{Rp~15.538}$ \\
\hline
\end{tabular}

Sumber: Hasil data diolah 
Berdasarkan tabel $5 \mathrm{di}$ atas, perhtungan pajak penghasilan setelah penerapan zakat diterapkan maka menggambarkan laba secara keseluruhan sebelum pajak pada PT Telkom Indonesia Tbk adalah sebesar Rp 20.336 Milyar dan total pajak yang harus dibayarkan pada tahun 2011 adalah sebesar Rp 4.698 Milyar.

Tabel 6. Pajak penghasilan setelah penerapan zakat pada PT Telkom Indonesia Tbk

\begin{tabular}{|c|c|}
\hline \multicolumn{2}{|c|}{ Tahun 2012} \\
\hline \multirow{3}{*}{\multicolumn{2}{|c|}{$\begin{array}{c}\text { PT TELKOM INDONESIA TBK } \\
\text { PERHITUNGAN PAJAK PENGHASILAN TAHUN } 2012 \\
\text { (Milyar Rupiah) }\end{array}$}} \\
\hline & \\
\hline & \\
\hline Laba & Rp 24.228 \\
\hline Zakat & $(\mathrm{Rp} 605)$ \\
\hline Laba sebelum Pajak & Rp 23.623 \\
\hline \multicolumn{2}{|c|}{ Pajak Penghasilan Terutang: } \\
\hline Pajak Kini & $(\operatorname{Rp} 5.905)$ \\
\hline \multirow[t]{2}{*}{ Pajak Tangguhan } & $\underline{\mathrm{Rp}} 762$ \\
\hline & $(\operatorname{Rp} 5.143)$ \\
\hline Laba Tahun Berjalan & Rp 18.480 \\
\hline
\end{tabular}

Sumber: Hasil pengolahan data

Berdasarkan tabel 6 di atas, perhtungan pajak penghasilan setelah penerapan zakat diterapkan maka menggambarkan laba secara keseluruhan sebelum pajak pada PT Telkom Indonesia Tbk adalah sebesar Rp 24.228 Milyar dan total pajak yang harus dibayarkan pada tahun 2012 adalah sebesar Rp 5.143 Milyar.

Tabel 7. Pajak penghasilan setelah penerapan zakat pada PT Telkom Indonesia Tbk

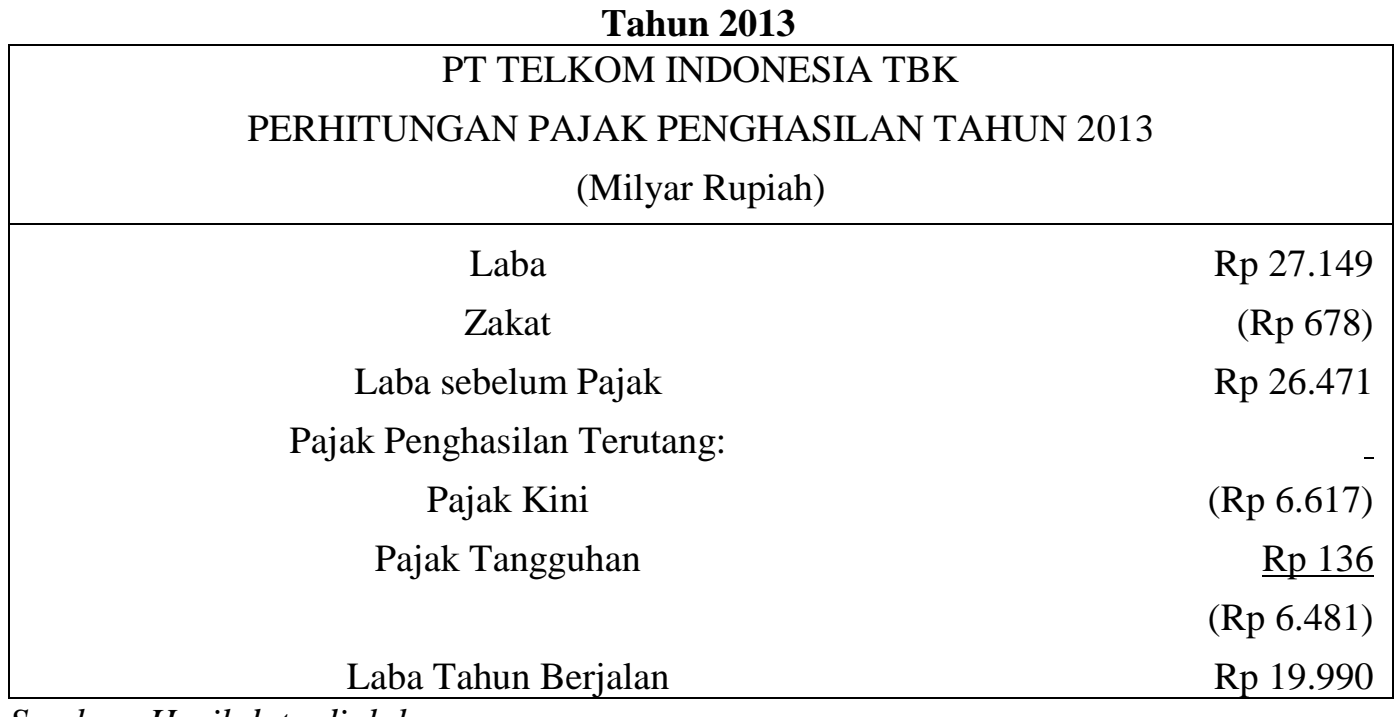

Sumber: Hasil data diolah

Berdasarkan tabel $7 \mathrm{di}$ atas, perhtungan pajak penghasilan setelah penerapan zakat diterapkan maka menggambarkan laba secara keseluruhan sebelum pajak pada PT Telkom Indonesia Tbk adalah sebesar Rp 27.149 Milyar dan total pajak yang harus dibayarkan pada tahun 2013 adalah sebesar Rp 6.481Milyar. 
Berikut data gambaran besarnya pajak setelah penerapan zakat pada PT Telkom Indonesia Tbk tahun 2011-2013:

Tabel. 8 Pajak penghasilan PT Telkom Indonesia Tbk mulai tahun 2011-2013 (Milyar Rupiah)

\begin{tabular}{ccc}
\hline Tahun & Besarnya Pajak & Selisih \\
\hline $\mathbf{2 0 1 1}$ & Rp 4.798 & - \\
$\mathbf{2 0 1 2}$ & Rp 5.143 & Rp 345 \\
$\mathbf{2 0 1 3}$ & Rp 6.481 & Rp1.338 \\
\hline Jumlah & Rp 16.422 & Rp 1.683 \\
\hline
\end{tabular}

Sumber: Hasil data diolah

Pada tabel di atas dapat dilihat besarnya pajak penghasilan setelah penerapan zakat pada sstem perpajakan PT Telkom Indonesia Tbk. Berdasarkan hadis Rasulullah saw menetapkan tarif zakat untuk penghasilan adalah sebesar $2.5 \%$ sehingga laba yang dihasilkan setelah zakat pada tahun 2011 adalah Rp20.336 Milyar, 2012 adalah 26.623 Milyar, dan tahun 2013 adalah 26.471 Milyar yang memengaruhi pula tarif pembayaran pajak.

Berdasarkan Undang-undang No 36 tahun 2008 yang menetapkan tarif pajak sebesar 25\% sehingga nilai pajak terutang pada tahun 2011 adalah Rp 4.798 (dalam Milyaran Rupiah, tahun 2012 adalah Rp 5.143 Milyar, dan tahun 2013 adalah sebesar Rp 6.481 Milyar.

Secara umum pajak penghasilan setelah penerapan zakat tetap mengalami peningkatan dari tahun 2011-2013. Dari tahun 2011 ke tahun 2012 pajak penghasilan meningkat sebesar Rp 345 Milyar atau dengan presentase sebesar 7\%. Begitupun untuk tahun 2012 ke tahun 2013 mengalami peningkatan sebesar Rp 1338 Milyar atau dengan presentase sebesar $26 \%$.

Secara visual perkembangan pembayaran pajak setelah penerapan zakat pada PT Telkom Indonesia Tbk untuk tahun 2011-2013 dapat dilihat pada grafik berikut:

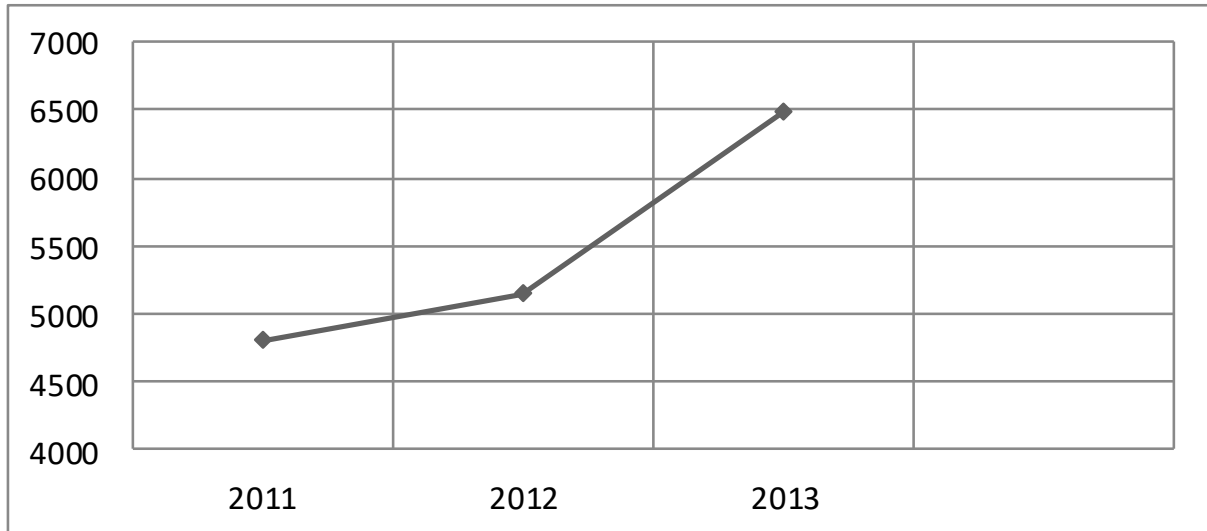

Gambar 2. Grafik Besaran Pajak penghasilan PT Telkom Indonesia tahun 2011-2013 setelah penerapan zakat.

Pada gambar 2 terlihat dengan jelas besarnya pajak penghasilan setelah penerapan zakat pada PT Telkom Indonesia Tbk. Mengalami penigkatan mulai dari tahun 2011-2013.

Analisis perbandingan besarnya Pajak Penghasilan terutang sebelum penerapan zakat dan besarnya pajak setelah penerapan zakat

Berdasarkan hasil analisis pada dua subbab sebelumnya maka penulis akan membahas mengenai dampak dan implikasi zakat terhadap pajak terutang pada tahun 2011 sampai dengan tahun 2013 di PT Telkom Indonesia Tbk, maka adapun perbandingan perubahan besarnya pajak penghasilan sebelum dan seudah penraan zakat dapt dilihat pada tabel 11 berikut ini: 
Tabel 9. Perbandingan Pajak Penghasilan PT Telkom Indonesia Tbk sebelum penerapan zakat dan setelah penerapan zakat Tahun 2011-2013 (Milyar Rupiah)

\begin{tabular}{|c|c|c|c|}
\hline Tahun & $\begin{array}{c}\text { Besarnya PPh } \\
\text { sebelum penerapan } \\
\text { zakat }\end{array}$ & $\begin{array}{c}\text { Besarnya PPh setelah } \\
\text { penerapan zakat }\end{array}$ & $\begin{array}{c}\text { Presentase selisih } \\
\text { penurunan }\end{array}$ \\
\hline 2011 & $\operatorname{Rp} 5.387$ & $\operatorname{Rp} 4.798$ & $12 \%$ \\
\hline 2012 & $\operatorname{Rp} 5.866$ & $\operatorname{Rp} 5.143$ & $14 \%$ \\
\hline 2013 & $\operatorname{Rp} 6.859$ & $\operatorname{Rp} 6.481$ & $5,8 \%$ \\
\hline
\end{tabular}

Pada tebel 9 di atas perbandingan besarnya pajak penghasilan sebelum penerapan zakat dan setelah penerapan zakat pada perencanaan perpajakan PT Telkom Indonesia Tbk selama Tahun 2011-2013. Perbandingan besarnya pajak sebelum dan sesudah penerapan zakat tahun 2011 mengalami penurunan sebesar Rp 580 Milyar atau dengan presentase penurunan sebesar $12 \%$, dimana besarnya PPh Badan yang dibayarkan sebelum penerapan zakat sebesar Rp 5.387 Milyar dan setelah diterapkan penerapan zakat diperoleh tarif besaran pajak sebesar Rp 4.798 Milyar.

Sedangkan perbandingan besarnya pajak sebelum dan sesudah penerapan zakat tahun 2011 mengalami penurunan sebesar Rp 723 Milyar atau dengan presentase penurunan sebesar $14 \%$, dimana besarnya PPh Badan yang dibayarkan sebelum penerapan zakat sebesar Rp 5.866 Milyar dan setelah diterapkan penerapan zakat diperoleh tarif besaran pajak sebesar Rp 5.143 Milyar. Dan untuk Perbandingan besarnya pajak sebelum dan sesudah penerapan zakat tahun 2011 mengalami penurunan sebesar Rp 378 Milyar atau dengan presentase penurunan sebesar $5,8 \%$, dimana besarnya PPh Badan yang dibayarkan sebelum penerapan zakat sebesar Rp 6.859 Milyar dan setelah diterapkan penerapan zakat diperoleh tarif besaran pajak sebesar Rp 6.481 Milyar. Berdasarkan hasil analisis pajak penghasilan yang harus dibayar perusahaan jika tanpa memasukkan zakat sebagai perencanaan pajak selama tahun 2011-2013 di PT Telkom Indonesia Tbk totalnya adalah Rp 18.109 Milyar dan jika melakukan perencanaan pajak dengan memasukkan zakat maka pajak yang harus dibayarkan total mencapai Rp 17.022 Milyar. maka dengan penerapan zakat ini telah terjadi potensi penghematan sebesar Rp 1.087 Milyar atau penurunan dengan presentase sebesar 6,3\%

Pajak penghasilan PT Telkom Indonesia Tbk menurun karena diterapkannya zakat sebagai komponen pengurang laba sehingga laba yang berkurang otomatis mengurangi pembayaran pajak, oleh karena itulah penulis mengusulkan zakat 2,5\% dibayarkan kepada badan amil zakat oleh perusahaan dapat disahkan oleh pemerintah sehingga dapat mengurangi penghasilan kena pajak berdasarkan perhitungan-perhitungan yang telah disampaikan pada subbab-subbab sebelumnya. Penerapan zakat ini selain dapat mengurangi penghasilan kena pajak sehingga mengurangi pajak juga untuk memenuhi kewajiban sebagai perusahaan yang pemilik dan manajemennya umat muslim, dari usulan tersebut perusahaan tidak perlu mengalami pengeluaran ganda karena kewajiban zakat dijadikan sebagai kewajiban pajak perusahaan yang berdiri dan beroperasi di Indonesia.

Dengan penerapan zakat pula perusahaan mendapatkan nilai-nilai non materil yang berorientasi pada agama seperti mendekatknan hamba kepada Tuhanya dan menambah keimananya, seperti ketaatan-ketaatan yang lain, faedah-faedah zakat pun terpenuhi dengan sistem ini. Alat pembersih harta dan penjagaan dari ketamakan orang jahat, ungkapan rasa syukur atas nikmat yang Allah SWT berikan, untuk pengembangan potensi ummat, dukungan moral kepada orang yang baru masuk Islam, menambah pendapatan negara untuk proyekproyek yang berguna bagi ummat Selain itu zakat akan memacu pertumbuhan ekonomi pelakunya dan yang jelas berkahnya akan melimpah, membayar zakat berarti memperluas peredaran harta benda atau uang, karena ketika harta dibelanjakan maka perputarannya akan meluas dan lebih banyak pihak yang mengambil manfaat. Dengan adanya penerapan zakat membuat komponen penghasilan kena pajak menjadi lebih rendah, sehingga PPh Badan yang 
harus dibayarkan pun lebih rendah. Hal tersebut menunjukkan bahwa dengan adanya penerapan zakat padan perencanaan pajak yang mengefisiensikan PPh badan yang harus dibayar PT Telkom Indonesia. Dengan melakukan penerapan zakat sebagai alat perencanaan pajak maka perusahaan memenuhi kewajiban sebagai perusahaan yang pemilik dan manajemennya umat muslim dan telah mengaplikasikan faedah-faedah Islam mengenai zakat. Penulis pun melihat bahwa pembayaran zakat sebagai kewajiban umat muslim sebaiknya dibayarkan oleh perusahaan sebagai satu pajak penghasilan badan oleh perusahaan tersebut. Adapun regulasi yang dapat dipertimbangkan bagi pemerintah adalah membuat undang-undang agar setiap perusahaan wajib melakukan pembayaran zakat sebagai komponen laporan keuangannya sehingga semua perusahaan dapat melaksanakan zakat yang sangat bermanfaat bagi perusahaan itu sendiri dalam berbagai hal.

\section{PENUTUP}

Berdasarkan hasil penelitian tentang Analisis penerapan Zakat sebagai alat perencanaan pajak (Tax Planning) PPh Badan pada PT Telkom Indonesia yaitu Terdapat potensi efisiensi perpajakan apabila melakukan perencanaan pajak dengan penerapan zakat sebesar 6,3\%. Perhitungan PPh Badan dengan melakukan penerapan zakat sebagai perencanaan pajak hasilnya lebih efisien dibandingkan tanpa melakukan penerapan perencanaan pajak. Selisih antara PPh Badan yang dilakukan penerapan zakat sebagai alat perencanaan pajak dengan tanpa dilakukan penerapan zakat sebagai perencanaan pajak yaitu sebesar Rp 1.087 Milyar, Perusahaan wajib mengeluarkan zakat karena keberadaan perusahaan adalah sebagai badan hukum (recht person) atau yang dianggap sebagai orang. zakat perusahaan yang pertama dapat diartikan sebagai pertanggung jawaban perusahaan kepada Allah Swt dan juga kepada delapan anshaf yang telah ditentukan. Zakat perusahaan sebagai pengurang pajak setiap tahunnya merupakan suatu berkah bagi perusahaan karena telah menunaikan suatu kegiatan spiritual dalam agama Islam juga telah melakusanakan corporate Social Responsibility kepada masyarakat.

\section{REFERENSI}

Andri Soemitra. 2009. Bank dan Lembaga Keuangan Syariah. Jakarta: Kencana.

Basir, Abdul. 2002. Thesis Zakat Atas Penghasilan Sebagai Pengurang Penghasilan Kena Pajak. Jakarta : UI FISIPOL.

Direktorat Jendral Pajak. 2001. Undang-Undang Nomor 17 Tahun 2000 tentang pajak Penghasilan.

Direktorat Jendral Pajak. 2009. Undang-Undang Nomor 36 Tahun 2008 tentang pajak penghasilan.

Fakhruddin. 2008. Fiqh dan Manajemen zakat di Indonesia. Malang: UIN Malang-Press.

Gunadi. 2013. Panduan Komperhensif Pajak Penghasilan. Jakarta: Bee Media

Gunadi. 2009. Akuntansi Pajak, edisi Revisi 2009. Jakarta: Grasindo.

Gunadi. 1997. Pajak Internasiaonal. Jakarta: Lembaga Penerbit FE UI.

Ikatan Akuntan Indonesia. 2009. PSAK 2009. Jakarta: Penerbit Salemba.

Khairrizal. 2019. zakat sebagai pengurangan penghasilan kena pajak. Surakarta: Universitas Muhammadiyah Surakarta.

Logawi Thamrin. 2018. Peranan zakat sebagai pengurang penghasilan kena pajak di kantor kementerian agama kabupaten Gowa. Makassar: Jurnal Laa Maysir

Mulyono. 2006. Akuntansi Pajak. Yogyakarta: Penerbit Andi.

Mulyono. 2009. Tax Planning., Yogyakarta: Penerbit Andi.

Mardiasmo. 2009. Perpajakan edisi Revisi 2009. Yogyakarta: Penerbit Andi.

Mufraini Arief. 2008. Akuntansi dan Manajemen Zakat Jakarta: Penerbit Kencana.

Pohan Anwar. 2013. Manajemen Perpajakan. Jakarta: PT Gramedia Pustaka Utama.

Purwono Herry. 2010. Dasar-dasar Perpajakan dan Akuntansi Pajak. Jakarta: Penerbit Erlangga. 
Reza Haikal. 2012. Mengangkat nilai "Zakat dengan hati" refleksi fenomenologis zakat perusahaan pengusaha Arab, Jurnal Akuntansi Multiparadigma 3(1).

Rivai veithtizal dkk. 2013. Islamic Banking and Finance. Yogyakarta: Penerbit Fakultas Ekonomika dan Bisnis UGM.

Rizal yaya. 2009. Akuntansi Perbankan Syariah: Teori \& Praktik. Jakarta: Salemba Empat.

Sugiyono. 2011. Metode penelitian kuantitatif \& kualitatif R\&D edisi ketiga belas. Bandung: Alfabeheta.

Wangaswidjaja. 2012. Pembiayaan Bank Syariah. Jakarta: Gramedia Pustaka Utama.

www.Telkom.co.id

www.tribunnews.com/bisnis/2013/10/11/perdagangan-bebas-apec-rugikan-indonesia diakses 25

Mei 2014

www.economy.okezone.com/read/2013/12/09/316/909308/peran-ekonomi-syariah-makinpenting diakses 25 Mei 2014

www.republika.co.id/berita/ekonomi/syariah-ekonomi/13/12/02/mx6hu5-ekonomi-syariahharapan-masa-depan-indonesia diakses 25 Mei 2014

www.ekonomisyariah.org/

www.usum.co/news/read/2013/12/03/pemimpin-industri-dunia-berkumpul-bahas-keuangansyariah/ diakses 25 Mei 2014

www.supry.web.id/2010/08/11/macam-macam-zakat/

www.youtube.com/watch?v=GTcMnpO7r80 diakses 25 Mei 2014

www.wikipedia.org/wiki/Agama_di_Indonesia. diakses 25 Mei 2014. 